\title{
Strategic Moves of the War-August 4th, 1915
}

\author{
By Capt. Matthew E. Hanna, Recently of the General Staff, U. S. A.
}

$A$ s these notes are written (August 4th) German decisive victory of the war. The circle of fire is being pushed ever closer about Warsaw, and from south, west north and northeast Teuton forces are driving with all their might against the Russian forces defending Poland. The world audience is witnessing what promises to be the successful termination of the most masises to be the successful termination of the most mas-
terful strategic plan of all military history. If we properly interpret the events in this theater during the year the war has continued, the situation on the Russian frontier to-day has not merely "happened" and taken its present form, so favorable to the Teutons, through mere lucky chance, but has resulted from the deliberate planning of the German General Staff and consistent adherence to its plans during the entire year of war.

Poland projects into German territory like a huge fist aiming its blow at Berlin. On three sides it is bordered by German territory. To the north is the narro strip of East Prussia, less than one hundred and fift miles wide, bordering on the Baltic Sea. To the south is the Austro-Hungarian province of Galicia, traversed from east to west by the Carpathian Mountains, one hundred to two hundred miles south of the Polish frontier. From the Baltic Sea in the north to the Carpathians in the south the distance is less than four hun dred miles at the narrowest point-a line none too long for an efficient offensive campaign by Russia's hosts, and on this front she could advance against the heart of Germany with her right flank protected by the Baltic sea and her left by the Carpathian Mountains. In the successful prosecution of such an advance, Poland, and more particularly the great city of Warsaw with its manufacturing facilities and splendid railroad communications, with the interior of Russia on one side and with the German frontier on the other, would form a military asset of very great value. Much has been written in the last few weeks of the purely accidenta way in which the Russians have been led into a defense of Polish territory, but this reads more like an apolog for the disaster which threatens them than sound military strategy, and is difficult to reconcile with the struggle they have made to hold this territory in the face of very great hazards.

More probably Russia has looked upon Poland, until quite recently, as a great base of operations for a decisive campaign against Germany, the leader of the Teuton alliance, and in surrendering it she is giving up strongly defended territory which must be recovered before Germany can be invaded, or, in other words, before the war can be terminated decisively in favor of the Allies. The conquest of Poland would be a stupendous victory for the Teutons, not so much because of what they would gain as because of what the allied cause would lose.

For months, while Germany was fully occupied in the western theater and Austria was left to struggle quite alone in the eastern theater, the Russian army made repeated efforts to advance its two wings through East Prussia on the north and Galicia on the south, and bring them on line with the center in Poland, for the center would have been in still graver danger had it been thrust farther toward Germany before the two wings were up and the whole line straightened out from the Carpathians to the sea. Despite the demands made on Germany by her campaign in France, she was able to keep a fairly strong force in East Prussia at all times, and by means of her admirable railroads has always succeeded in sending re-enforcements to this region from France in sufficient numbers to check and then drive back the Russian forces that have penetrated East Prussia from time to time. As a result, the Russian offensive north of Poland has never met with any lasting

To the south of Poland, in Galicia, the Russian advance was most successful throughout the first nine months of the war, and was not stopped until practically all Galicia had been conquered, the Carpathians crossed and Hungary imminently threatened with invasion. From time to time during this period Germany had bolstered up the failing strength of her ally with such troops as she could ill spare from her western campaign, but never without doing little more than check the victorious Russian onslaught and prevent it from reaching a phase beyond all control. Fortunately for the Teutons, before this could happen the Germans were able to dig themselves so securely into the ground, from the North Sea to Switzerland, that they could safely transfer the bulk of their forces from the west to the east and turn against Russia as the giant first to be destroyed. This was in April. For nine months the Teutons bad struggled to bang on to the territory north and south of Poland, partly to prevent Russia from securing the great benefit that would be hers if she could form her army on a straight line from Danzig south through Cracow to the Carpathians, but mainly because this territory was to be of vital importance in
the great offensive campaign ultimately to be waged against Russia.

The great central idea of this campaign was to entice a part of the Russian army deep into the bag formed by Poland and strive by every conceivable stratagem not only to keep it there, but to add to its strength from day to day, while in the meantime planning and executing arrangements to bring the campaign to a decisive climax by closing the mouth of the bag east of Warsaw. When Germany set out to do this, in April, she held all of East Prussia and was in the desired position north of Poland, but to the south the Russian army must be pushed back nearly two hundred miles through Galicia before the Teuton advance against Warsaw could be made advantageously from this direction. At that time the Russian line ran almost due south through western Poland, passed to the east of Cracow, crossed the Carpathians (south of the southern edge of the map), and

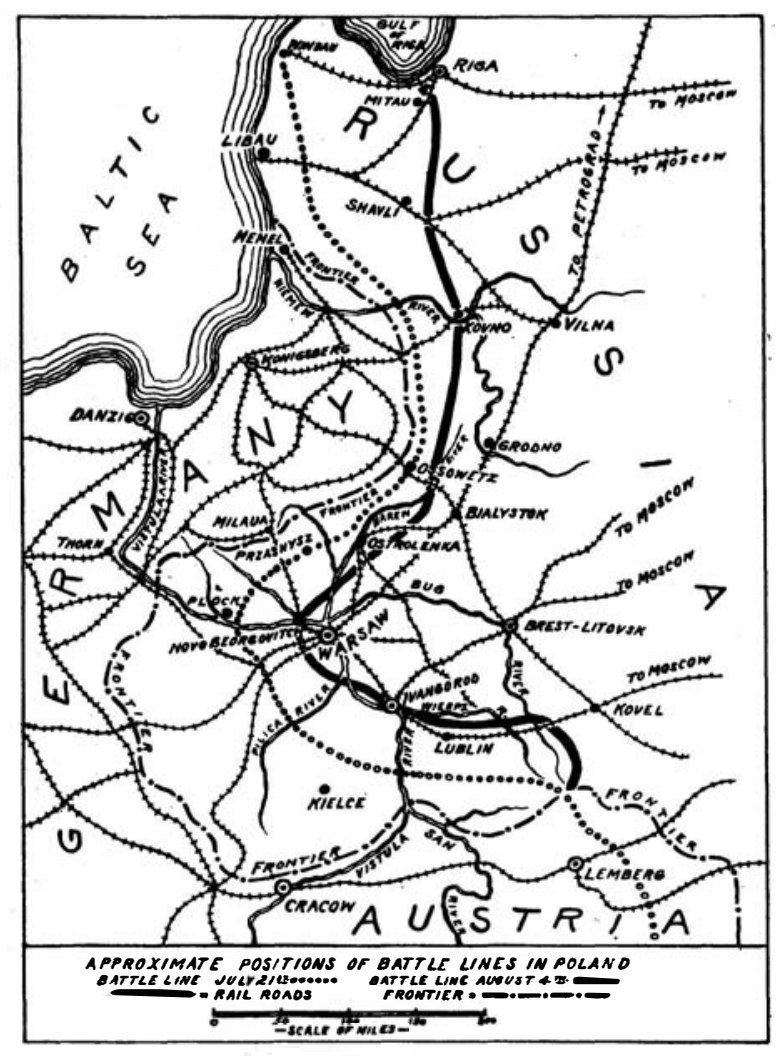

The closing in of the Teutonic lines upon Warsaw.

then bent to the eastward. With a thoroughness not excelled in any previous war, Germany now made her preparations for the first stage of the colossal campaign which is reaching its climax as these notes are written. From the French battle front, from all parts of Germany and from the northern portions of her line in Russia she assembled men, artillery, ammunition and war supplies of all kinds in the region of Cracow, and when all was ready began her impetuous drive through Galicia that was scarcely checked until practically all Galicia had been recovered and the Russian line had been bent well back to the eastward on the south of Warsaw, and the bag for the capture of a part of the Russian army had been formed.

This ended the first stage of the campaign, and with the same thoroughness as before, arrangements were made for the second stage, which was to be a simultaneous advance from north and south in the genera direction of Brest-Litovsk to close the mouth of the bag. Again there was a considerable period of comparative calm, probably utilized by the Teutons in shifting their troops for the changed direction of the attack, and in bringing up ammunition and supplies. The reports indicate that the operations preliminary to the decisive advance now in progress were so skillfully managed that the Russians played into the Germans' hands by moving strong re-enforcements into the Warsaw region and thereby adding to their disaster should the German advance be successful.

Some months ago the Germans captured the port of Libau, on the Baltic Sea. Little notice was taken of this at the time, for considered as an isolated operation it was not deemed important, particularly in the face of events of vast magnitude and importance taking place elsewhere at that time. More recently they have captured the port of Windau, a little farther north on coast, and the German troops in this region have been greatly. re-enforced. It was suggested in these notes some weeks ago that this army probably was being collected in this district for some important mission at a later. date, and it now turns out that this force may be the final decisive factor in the campaign, placed in its present strong strategic position at an opportune moment long before the campaign had assumed its present critical stage. It was not possible to support a large force in this region without first capturing the two coast towns of Libau and Windau and getting possession of the railroads leading from them into the interior. Overland operations into this region by forces moving from East Prussia were not practicable because of the lack of railroads between the frontier and the Libau-Vilna Railroad, seventy-five to one hundred miles from the frontier.

It needs but a glance at the map to see the important strategic position the Germans have thus secured on the northern wing of the Russian army. This greatly broadens the possibilities of the campaign, while materially increasing Germany's chances for success in the campaign. A German advance from this region endangers the important railroad running from Warsaw to Petrograd and threatens to envelop the right wing of the Russian army in such manner as to cut it off from Petrograd and compel it to withdraw much farther east than would be necessary if its right wing were securely unchored on the Baltic Sea.

No doubt the Russian plan from the beginning of the war has been to occupy a general north and south line through Brest-Litovsk in case it became necessary to abandon Poland. The left wing of the army would then be strongly posted on the Dniester River (just south of the territory shown on the map), the center would be behind the Bug River and the powerful fortifications of Brest-Litovsk, and the right wing would be fully protected by the sea. The total length of this front is approximately five hundred miles, and the Russian army would be capable of defending this line quite as stubbornly as the French and English have defended a somewhat shorter line in the west. But with the Germans in full possession of the Baltic coast as far as the Gulf of Riga, the Russian right wing must bend sharply to the eastward, pivoting on Brest-Litovsk, and will be "in the air." A continuation of the German advance from the general direction of Riga might bend back this wing of the Russian army to such an extent as to form another prominent salient in their line at Brest-Litovsk similar to that now existing at Warsaw. The operations of the German army to the south of Brest-Litovsk are also tending to produce this situation. The Germans have succeeded in crossing the Bug River and are pushing toward Kovel, so that while complet ing the circle about Warsaw they are at the same time beginning to weld a ring around Brest-Litovsk.

If the Germans continue to meet with success in this campaign, its further development probably will be divided into two distinct stages, the first of which will terminate with the capture of Warsaw and the conquest of Poland. The Russian line cannot make an other stand before reaching Brest-Litovsk, and from here it probably will run about due north through Vilna. After a period of some days-for recuperation and rearrangement of troops-we may see the Germans begin the second stage, consisting of a wide turning movement to the north of Vilna against the Russian right wing, which would rival in magnitude the initial drive of the Germans through Belgium and northern France against the French army in front of Paris. And here, as in France, the purpose of such a drive would be the destruction of the army opposed to them. If the Russians should prove to be not strong enough to hold the strongly fortified region of Poland, there is much less chance of their being able to hold a weaker second line, especially if their losses in Poland should be out of proportion to those borne by the Germans, as most probably will be the case if the Russians must abandon the Warsaw lines. More than ever before will Germany be confronted with the necessity of continuing the Russian campaign, if she is to get the full benefit of her previous victories. The time when she can once mor turn her attention to her western front in France still appears to be far away.

The world continues to wonder why the Allies in the west cannot do more to relieve the pressure on Russig. Italy is doing her share with her steady pressure on the Austrians along the Isonzo, and is preventing re enforcements being sent from this theater to aid the Teutons in Russia, but we hear persistent reports of German troops being withdrawn from in front of the French and English to operate against Russia. If the 
Allies in France are not strong enough to prevent this being done, with Germany's lines in this theater already greatly weakened, what will they do if Germany eventually is able to shift a million or more men to the west and undertake a second drive on Paris much more powerful than that of the first weeks of the war? The inactivity of the western Allies may be satisfactorily explained when all the facts eventually are known, but with the information before us now, we cannot avoid the conclusion that there is lack of co-operation between the Allies on the two great battle fronts. More than once in the opening months of the war, when France was undergoing her supreme trial, Russian activity in the east saved France at critical stages of her campaign. But for three months the fortunes of war have steadily gone against Russia, until to-day she is confronted by a situation so critical as to threaten disaster not only to her main army, but to the entire allied cause, and yet France and England are doing nothing out of the ordinary, so far as the world can see, to checkmate the German success in the east.

The great war has entered its first decisive phase, and for the present the balance hangs low in favor of the Teutons But the Russian army is still intact and far from being destroyed. If it can save itself from disaster in the next few weeks, if Italy can continue to press forward on the Isonzo, and if France and England can begin operations that are up to the expectations of the world, winter may see the balance of strength restored and the contending forces on an equal footing for a fresh start.

\section{A New Discovery in the American Wine Industry}

TE American Department of Agriculture announces method for concentrating grape juice, which promises to. be the greatest discovery in the wine industry since Pasteur discovered the method of preserving light wines for the French government.

This new method is altogether novel, as it consists not in boiling down the juice, but in freezing the juice. The ice is then cracked into small pieces and whirled in a centrifugal machine; by this means all the sugar and thick syrup is separated from the ice, which is a)most pure water. By this means a gallon of the syrup is reduced to one quart.

A peculiar phenomenon incident to this process is the fact that the cream of tartar crystallizes out with the ice and makes the acidity of the juice much less than normal. This is particularly true of the Concord grape juice, which has a large percentage of tartar in it.

This new method of freezing the juices to concentrate them preserves in a wonderful degree the natural purple color of the juice and makes the drink very much more beautiful in its rich purple appearance and more sparkling.

When the concentrated juice is sterilized afterward by heating it keeps indefinitely as a thick syrup. It can be used at soda fountains, as flavorings for cookery and other dietary purposes. The Government hopes to exploit this latest discovery on a commercial basis this sear, as it promises not only to give a fine quality of goods from the best grapes, but also the freezing method takes out the "rough" taste of many cheaper grades and gives a very fine article from the cheaper and coarser varieties.

\section{The Work Done by German Guns}

THE cartridge used in the German infantry rifle marked M 98, contains 3.2 grammes, or about 0.112 ounces avoirdupois of powder, which on explosion cre ates 2,762 calories, or 10,960 British thermal units, corresponding to 1,170 kilogramme-meters, or 8,463 footpounds. Of this one third is utilized in creating the initial velocity of the bullet of 820 meters, or about 2,690 feet per second, and in imparting the rotative motion. One quarter of the energy is lost in heat to the barrel and 45 per cent passes away in sound energ. and the escaping gases. The bullet passes out of the barrel in 1/200 of a second, and during this time a pressure of 5,600 atmospheres, or 51,450 pounds per square inch is acting within the barrel.

The largest guns used on German warships have a bore of 40.6 centimeters (16 inches), and the firing of one of these guns represents 41,500,000 kilogramme meters, or 300,000,000 foot-pounds. This is equal to the impact that woul' result from the fall of a block of granite 30 feet long, 30 feet wide and 20 feet thick dropped from a height of 110 feet.

The 30.5-centimeter (12-inch) Krupp gun fires a. projectlle weighing 445 kilogrammes (981 pounds), which leares the barrel with a velocity of 2,690 feet a second. Their maximum range is 20 kflometers, or about $121 / 2$ miles, and the shot covers this distance in 95 seconds If coe of these guns. is: fired in a due northi and: south direction the projectile will deviate a distance of 160 meters, or 525 feet from its true direction, owing to the revolution of the earth;

\section{(Intrezpmùnerp}

le for statements made in the correspondence column. Anonymous communications cannot be considered, but the names of corre spondents will be withheld when so dcsired.]

\section{Lightning Without Rain}

\section{To the Editor of the Scientific American :}

A peculiar lightning display occurred here on the morning of Tuesday, June 22nd, which I should like to displays are at all common.

There had been a severe thunderstorm accompanied by heavy rain between 1 and $2 \mathrm{~A}$. M., but by daylight the rain had stopped. Tuesday morning was cold and damp, with a very cloudy sky. At about ten minute after $11 \mathrm{~A}$. M. there occurred a most terrific lightning display over an area about half a mile wide and over a mile in length. "Lightning balls" and flashes were seen all over this area, and at the same instant there was a tremendous single thunder clap that sounded like an explosion of dynamite. There were no reverberations of the thunder.

I was on the ground fioor of my home, which is near the center of the area affected. I saw a flash in the hallway resembling the discharge between the points of a high power induction coil, and heard a shary crackling sound above the noise of the thunder or else im mediately preceding it. On both second and third floor of the house "lightning balls" were seen passing down the hallways, as well as one in the kitchen in the rear of the house. For a few moments afterward there was a distinct smell of ozone in the air. No damage what ever was done except that the lightning arrester of the telephone was blown out.

Exactly similar effects were noticed at houses a quarter of a mile to the north and a quarter of a mile $t$ the south of my home, and at many places in the tow of Freeland, about a mile to the east. Several 'phones were blown out. In one case of three 'phones on the same line, two were blown out, while the third was not. The telephone operator at the Freeland exchange said that "balls of fire" issued from most of the plugs on the switchboard. Persons who were out of doors at the time describe "balls of flre" dropping from the sky and exploding on hitting the ground.

Everyone describes the noise of the thunder as being "close at hand" and coming at the same instant as the lightning.

No damage was done except the slight injury to the telephones, and no one was injured. No rain fell at the time, and we had no further electrical disturbance unt about half past three in the afternoon, when we had another fairly severe thunder shower.

If you can throw any light on this occurrence I shal steem it a great favor.

E. J. D. Coxe.

\section{Drifton, Pa.}

[A discharge of lightning without rain is unusual but not rare. During rapid convection, electrical separation is produced in such manner that the larger rain drop usually become charged with positive electricity and the'smaller with negative. Hence, even after the generation of electricity has ceased the remaining cloud is likely still to be highly charged and thus capable of producing a final flash.

The "balls of fire" on the telephone switchboard, and probably most of those seen at other places, doubtless were either ramifications of the main discharge or else return discharges due to the sudden change of potential caused by the first flash.-EdrTor.]

\section{A Former Patent Commissioner on the Patent Ofiice in the Old Days}

To the Editor of the Scirvriric Ambricar:

I am advised that you are about celebrating the seventieth anniversary of the Scientific American. Your latest issue lies upon my desk. It is almost exactly a half century since I received the first. It was young then, but fresh and interesting and instructive every week. Increased in scope, it has kept pace with the years, and I still read. it with unabated interest. But I recall the fresh impressions formed in those early years, and I particularly remember your representatives in Washington, of those earlier years, the Knights and Gridley, men of ability and high character and service, well continued in their successors.

This anniversary brings to my mind a flood of eminiscences of a half century ago.

Compared with its present admirable condition, everything in the Patent Office of that time appears to me now to have been rather crude. In the class of railway and civil engineering, in which my lot fell, there were three of us, an examiner, a first assistant and myself, then a raw recruit metamorphosed from a veteran commander of a brigade, in theory into an acting second assistant, then the lowest grade.

But everything was new to me and intensely interestIng. My duties as second assistant included the reep-

ing of the books and care of the files. Examiners' clerks had not then been invented. This clerical work, however, occupied only the morning hours, and the remainder of the day was devoted to examination "of applications. In my case it also included much study, as there had been nothing in the Army Regulations and Casey's Tactics, the text books of the previous years, which was applicable to the present business.

Fifty years ago the record behind us, the "state of the art," was a much smaller field and simpler. Yet of this we had comparatively scant records. In the examiner's room there was nothing excepting a few text books, no copies even of our own patents, and we were obliged, in making searches, to go to the draftsman's room and handle huge portfolios, pulled out from rollers and rested on the floor. Our principal examiner, when he applied himself to such labor, would bring down a huge assortment, and then see more critically what he could find in the mass. His acuteness varied, and toward the close of the month, if there were many cases on hand, remoter references were useful. The library was far less extensive and less available than now. One old librarian, who remembered enormously but principally by resemblances, did much to put us on unprofitable searches.

The examining corps had not then been selected by competitive examinations.

There was an examination, in strict propriety called " "pass examination" and if you were sent before it you "passed" not otherwise. The story was then told (and I believe it to be true-I knew the man) of one candidate who, when asked the distance of the sun from the earth, replied that he did not know, but was sure that it was so far as not to interfere with his duties as an assistant examiner. He "passed," and it is fair to say became afterward a principal examiner, and a good one.

There were many good men in the corps, notwithstanding the imperfect system.

There were two, or perhaps three, ex-governors of States. There were some graduates of colleges, but most of miscellaneous previous occupations. One principal examiner had acquired his fitness by reporting theatrical matters for newspapers. There were many bright young men, however, who by diligence and intelligence became expert. The great majority of these, as well as of the attorneys who then practised before the Office, are now, alas, dead. Of those who were in the examining corps in 1865, when I entered, only one remains.

Indeed, since that date the personnel of the Office has, in the main, many times changed.

I have observed the Office during all those fifty years, and without reflection on the men and methods of that early date, I know that there has been constant and now immense improrement both in material equipment, in personnel, and in methods. This has largely been due to causes within the Office, but the efforts of intelligent attorneys and the illuminating decisions of the courts have aided greatly also in bringing about an orderly and settled practice. Elis Spear. Washington, D. C

\section{The Cryogenic Laboratory of Leyden}

\section{To the Editor of the ScIENTIFIC AMErican:}

When reading your very interesting article on Prof. Kammerlingh Onnes's work in your issue of February 13th last, I remember having read in the English paper Nature, in one of the years 1895 to 1899 , an article on the Cryogenic Laboratory in Leyden, with a small illustration of the very modest installation of that time, so $I$ think it was not your paper that made first mention of said laboratory in the English language. In those times, Leyden being one of the four existing cryogenic laboratories, was worth mentioning for that reason only. Kindly compare the old illustration with your own recent ones, which will show the progress of that laboratory during that period. In the case you were not aware of the old article in Nature, I write you these lines, which might interest you. $\quad$ J. M. GEULs. Bandoeng, Java.

\section{Belgian and American Co-operation} To the Editor of the Scientific America* :

I should be very glad if you would inform your readers that several Belgian competent business men have reated an organization having a double object:

1. To introduce in Belgium, as soon as the war is ver, all American products and manufactures, etc

2. To employ as agents, representatives. etc., a large number of Belgian manufacturers and business men 